\title{
Assessment of Soil Nutrients Limiting Sustainable Potato Production in the Highlands of South-Western Uganda
}

\author{
Robert Muzira1, Twaha Basambaㄹ, John Steven Tenywa ${ }^{2}$ \\ ${ }^{1}$ National Agricultural Research Organization, Mbarara, Uganda \\ ${ }^{2}$ Makerere University, Kampala, Uganda \\ Email: nrmuzira@yahoo.com
}

How to cite this paper: Muzira, R., Basamba, T. and Tenywa, J.S. (2018) Assessment of Soil Nutrients Limiting Sustainable Potato Production in the Highlands of South-Western Uganda. Open Access Library Journal, 5: e4440.

https://doi.org/10.4236/oalib.1104440

Received: February 22, 2018

Accepted: March 11, 2018

Published: March 14, 2018

Copyright $\odot 2018$ by authors and Open Access Library Inc.

This work is licensed under the Creative Commons Attribution International License (CC BY 4.0).

http://creativecommons.org/licenses/by/4.0/

\begin{abstract}
Soil fertility management is one of the major strategies for improving potato productivity in the highlands of south-western Uganda. Land belonging to potato farmers is highly fragmented hindering sustainable potato production under small-holder farming systems. Land fragmentation brings a major challenge to small-scale farmers in soil fertility management, increasing costs of production. However, identifying major soil nutrients limiting potato production in the highlands of south-western Uganda is an avenue of applying appropriate soil nutrients to improve potato productivity without degrading the soils. It also assists farmers in investing in the necessary soil nutrients and, hence reducing the costs of production while improving potato productivity. The study indicated that soil potassium was the most single significant soil nutrient limiting potato productivity especially in the fields located on hilltops and far from homesteads. Hence, it was imperative that farmers apply potassium containing fertilizers to minimize potassium depletion but also increase potato productivity. It was also important for farmers to always integrate disease management with soil nutrient management for improved potato productivity.
\end{abstract}

\section{Subject Areas}

Soil Science

\section{Keywords}

Land Fragmentation, Potato Productivity, Soil Nutrients, Yields

\section{Introduction}

Advances in agricultural production techniques have stimulated an average an- 
nual growth in global per capita consumption of $0.3 \%$ [1]. Despite these impressive achievements in both income and consumption, more than one billion people in the developing world are poor, apparently surviving on less than US\$ 1 a day [2]. In Uganda, declining soil fertility is among the major factors constraining food production and economic performance of small scale farms [3]. Diminishing soil fertility and crop productivity in the highlands of south-western Uganda have been associated with low use of improved technologies such fertilizers and manures [4]. Lack of market opportunities for farmers' produce has been one of the disincentives for increased agricultural production. Thus, Uganda is listed among the countries with the lowest crop yields per unit area in the world, in spite of its relatively favorable agro-climatic environment [5].

To reduce food insecurity and poverty at household level, the government of Uganda has initiated various liberalization policies to revitalize agricultural production and improve rural household income [6]. Subsequently, the government has urged farmers to embrace agricultural modernization and produce for the market. In response, International Center for Tropical agriculture (CIAT), in collaboration with Africare-Uganda and NARO, has trained farmers in the highlands of south-western Uganda in improved soil fertility management technologies for sustainable potato (Solanum tuberosum L.) production. The same farmers were later linked to urban markets with good prices for potato produce. It was envisaged that integration of enhanced farmers' knowledge in soil fertility management and profitable markets could be an incentive for farmers to invest part of potato proceeds in soil nutrient management. To reduce land degradation and costs of production in form of investments in soil nutrient management, it was imperative to investigate soil nutrients limiting potato production on fields located on the different slope positions and distances from homesteads. It was also necessary to assess responses of potato yields on integrated soil nutrient management in fields located on different slope positions and distances from homesteads. This would guide farmers on which kind of soil nutrients to apply and therefore invest resources appropriately.

\section{Materials and Methods}

\subsection{Study Site}

This study was conducted in Kabale District in the highlands of south-western Uganda with farmers linked to urban markets. Kabale District covers an area of approximately 1800 square kilometres and lies between $-1.20774^{\circ} \mathrm{S}$ and $29.98588^{\circ} \mathrm{E}$ at an elevation of 2076 meters above sea level at the Uganda-Rwanda boarder. The mountainous terrain of Kabale District is part of the northern slopes of the Mufumbiro Range which encompasses the tallest mountain, Muhavura (4127 $\mathrm{m})$. The highlands of Kabale are composed of the Karagwe-Ankolean rock system which is largely of Precambrian age. The uplift to its present level occurred in association with the formation of the Western Rift Valley in East Africa. The highlands are dominated by steeply sloping ridges, hills and narrow valleys [7]. 
The highlands have steep long slopes that are intensively cultivated for potato under low input production systems [4]. Kabale has a population density of 144 persons $\mathrm{km}^{-2}$ and it is considered among the most densely populated districts in Uganda [8]. The district has a montane type of climate with an annual rainfall of $800-1000 \mathrm{~mm}$. The long rains occur between mid August-December, followed by short rains in mid March-May and a short dry spell between June and July [9]. Subsequently, Kabale is food self-sufficient, although the soils have over time been losing fertility due to over cultivation, soil erosion and lack of resources for soil fertility rejuvenation [4]. The soils on hill slopes are shallow dark brown with low productivity, while the valley bottoms have deep humose brown loam with moderate to high productivity. Fragmentation of land holdings is severe and the average landholding is about 0.32 ha per household [4].

\subsection{Research Approach}

\section{a) Selection of potato fields}

Six parishes in Kamuganguzi Sub County were selected based on their common bio-physical features and characteristics (land use types, plot sizes, soil types and vegetation). Using farmer group research approach, potato fields located on different slope positions and relative distances from owners' homesteads were selected. Using farmers' perception on soil depth, relative position on hill-slopes and fertility levels, potato field typologies were determined. These were either confirmed or placed in the corrected field typologies (hilltop \pm homestead, mid slope \pm homestead and valley bottoms) during field transect walks with community members.

\section{b) Soil sampling and laboratory analyses}

Soils from different field typologies were sampled at depth of $0-15 \mathrm{~cm}$ and analyzed for chemical (soil $\mathrm{pH}$, total organic matter, total $\mathrm{N}$, extractable $\mathrm{P}$, exchangeable $\mathrm{K}, \mathrm{Na}, \mathrm{Mg}$ and $\mathrm{Ca}$ ) and physical (soil bulk density) properties [10] [11].

\section{c) Limiting nutrient and fertilizer response trials}

Trials on limiting nutrients and fertilizer responses in potato on different field typologies were set up in six parishes in two rain seasons of 2017. Fertilizer treatments (Table 1 and Table 2) were randomly applied in plots of $4 \mathrm{~m} \times 3 \mathrm{~m}$ which were planted with pre-sprouted potato variety (Victoria) at spacing of 75 $\mathrm{cm} \times 30 \mathrm{~cm}$. Each of the trial on limiting nutrients and fertilizer responses had 30 trials located on different field typologies. Analytical copper chloride $\left(\mathrm{CuCl}_{2}\right)$, zinc chloride $\left(\mathrm{ZnCl}_{2}\right)$, manganese chloride $\left(\mathrm{MnCl}_{2}\right)$ and Analytical Borax $\left(\mathrm{Na}_{2} \mathrm{~B}_{4} \mathrm{O}_{7}\right)$ were sources for $\mathrm{Cu}, \mathrm{Zn}, \mathrm{Mn}$ and $\mathrm{B}$ respectively. Each of the micronutrients $(\mathrm{Cu}$, $\mathrm{B}, \mathrm{Zn}$ and $\mathrm{Mn}$ ) was applied at the recommended rate of $1 \mathrm{~kg} \mathrm{ha}^{-1}$. Land preparation, planting and weeding were carried out using a hand hoe. At maturity (100 days after planting), the number of plants per plot were recorded before harvesting. Plants from the middle four rows in each plot were harvested and the number of tubers per plant and their grades recorded. The three grades were assessed by measuring the circumference of tubers. These were Grade A ( $>60 \mathrm{~mm})$, Grade B $(45-60 \mathrm{~mm})$ and Grade C $(<45 \mathrm{~mm})$. Grades A and B are marketable 
Table 1. Fertilizer application for limiting nutrient assessment.

\begin{tabular}{ccccccc}
\hline \multirow{2}{*}{ Treatment } & $\mathbf{N}$ & $\mathbf{P}$ & $\mathrm{K}$ & $\mathbf{S}$ & $\mathbf{M g}$ & Micronutrients \\
\cline { 2 - 7 } & & & \multicolumn{3}{c}{$\left(\mathrm{kg} \mathrm{ha}^{-1}\right)$} & \\
\hline 1 & 0 & 0 & 0 & 0 & 0 & Control \\
2 & 100 & 100 & 100 & 40 & 35 & With micronutrients \\
3 & 0 & 100 & 100 & 40 & 35 & With micronutrients \\
4 & 100 & 0 & 100 & 40 & 35 & With micronutrients \\
5 & 100 & 100 & 0 & 40 & 35 & With micronutrients \\
6 & 100 & 100 & 100 & 0 & 35 & With micronutrients \\
7 & 100 & 100 & 100 & 40 & 0 & With micronutrients \\
8 & 100 & 100 & 100 & 40 & 35 & 0 \\
\hline
\end{tabular}

Fertilizer carriers were: Urea-source of N; Triple superphosphate (TSP) - source of P; Muriate of potash (MOP) - source of K; Single superphosphate (SSP)-source of P and S; Analytical magnesium oxide $(\mathrm{MgO})$ - source of $\mathrm{Mg}$; Analytical copper chloride $\left(\mathrm{CuCl}_{2}\right)$ - source of $\mathrm{Cu}$; Analytical zinc chloride $\left(\mathrm{ZnCl}_{2}\right)$-source of $\mathrm{Zn}$; Analytical manganese chloride $\left(\mathrm{MnCl}_{2}\right)$ - source of $\mathrm{Mn}$ and Analytical Borax $\left(\mathrm{Na}_{2} \mathrm{~B}_{4} \mathrm{O}_{7}\right)$ - source of $\mathrm{B}$.

Table 2. Fertilizer rates applied in potato response trials.

\begin{tabular}{ccccccl}
\hline \multirow{2}{*}{ Treatment } & $\mathbf{N}$ & $\mathbf{P}$ & $\mathbf{K}$ & $\mathbf{S}$ & $\mathbf{M g}$ & Micronutrients \\
\cline { 2 - 6 } 1 & & & & & $\left(\mathrm{~kg} \mathrm{ha}^{-1}\right)$ & \\
\hline 2 & 100 & 100 & 100 & 40 & 35 & Control \\
3 & 0 & 100 & 100 & 40 & 35 & With micronutrients \\
4 & 33 & 100 & 100 & 40 & 35 & With micronutrients \\
5 & 66 & 100 & 100 & 40 & 35 & With micronutrients \\
6 & 100 & 0 & 100 & 40 & 35 & With micronutrients \\
7 & 100 & 33 & 100 & 40 & 35 & With micronutrients \\
8 & 100 & 66 & 100 & 40 & 35 & With micronutrients \\
9 & 100 & 100 & 0 & 40 & 35 & With micronutrients \\
10 & 100 & 100 & 33 & 40 & 35 & With micronutrients \\
11 & 100 & 100 & 66 & 40 & 35 & With micronutrients \\
\hline
\end{tabular}

potato ware while grade $\mathrm{C}$ is considered seed size [4].

\subsection{Statistical Analyses}

The collected data were entered in Excel software for management and later analyzed using statistical software Genstat. Interactions of the different treatments were determined and Fisher's LSD test was used to compare each pair of treatments analyzed using One-Way ANOVA (Analysis of variance).

\section{Results and Discussion}

\subsection{Farmers' Perceptions on Soil Characteristics with Scientific Determinations}

Farmers were knowledgeable on the different levels of fertility and depths of po- 
tato fields located on the different slope positions (Table 3). Potato fields located on the upper slopes were often shallow with stony outcrops and extremely low fertility. This was an indicator of serious soil erosion and limited use of soil fertility improving innovations. The hill-slopes of the highlands of south-western Uganda were long and steep with high levels of erosivity [7]. Due to low soil fertility on upper slopes resulting into low potato yields, farmers often encroached and cultivated marginal areas such as wetlands as they searched for fertile soils. Soils in potato fields located in the valley bottoms were deep and fertile. These were extensively cultivated with limited use of soil fertility improving innovations such as fertilizers and manure that resulted into extensive soil nutrient mining.

\subsection{Soil Physical and Chemical Properties of Potato Fields under Urban and Non-Market Linkages}

Potato fields had soil extractable phosphorus (P) above the critical value of 15 $\mathrm{mg} / \mathrm{kg}$, below which potato growth could be negatively affected [12]. Soil nitrogen $(\mathrm{N})$ and potassium $(\mathrm{K})$ were inadequate and yet, they are heavily utilized by potato crop [12]. Among the soil parameters measures, only total soil carbon (SOC) and $\mathrm{N}$ that significantly varied with the farmer-market linkage types $(\mathrm{p}<$ 0.05) (Table 4). However, total SOC and $\mathrm{N}$ were below the critical value for optimum potato production [10]. Farmers under urban and non-urban market

Table 3. Farmers' perceptions on soil rating on landscape.

\begin{tabular}{ccccc}
\hline Map unit & Land-form & Soil fertility & Soil depth & Estimated soil depth \\
\hline 1 & Hilltops & Extremely low & Shallow & $30 \mathrm{~cm}$ \\
2 & Shoulders & Extremely low & Very shallow & $10 \mathrm{~cm}$ \\
3 & Back slopes & Very low & Shallow & $15-20 \mathrm{~cm}$ \\
4 & Foot slopes & Low & Fairly deep & $50-80 \mathrm{~cm}$ \\
5 & Valley bottoms & Medium/Good & Deep & $>100 \mathrm{~cm}$ \\
\hline
\end{tabular}

Table 4. Variation of soil properties in potato fields with urban and non-urban market linkages.

\begin{tabular}{|c|c|c|c|c|c|c|c|c|}
\hline \multirow{2}{*}{ Market type } & $\begin{array}{l}\text { Bulky } \\
\text { density }\end{array}$ & $\mathrm{Ca}$ & $\mathrm{Mg}$ & $\mathrm{K}$ & $\mathbf{P}$ & SOC & $\mathbf{N}$ & \multirow[t]{2}{*}{$\mathrm{pH}$} \\
\hline & $\left(\mathrm{g} / \mathrm{cm}^{3}\right)$ & \multicolumn{3}{|c|}{$(\mathrm{cmolc} / \mathrm{kg})$} & $\mathrm{mgkg}^{-1}$ & \multicolumn{2}{|c|}{ (\%) } & \\
\hline Urban & 1.88 & 5.46 & 2.17 & 0.51 & 41.4 & 1.92 & 0.15 & 5.6 \\
\hline Non-urban & 1.86 & 5.84 & 2.29 & 0.71 & 47.7 & 1.49 & 0.11 & 5.9 \\
\hline LSD & ns & ns & ns & ns & ns & 0.34 & 0.03 & ns \\
\hline CV (\%) & 24.15 & 54.36 & 56.07 & 75.56 & 61.34 & 34.40 & 42.00 & 13.60 \\
\hline $\begin{array}{l}\text { Critical } \\
\text { values }\end{array}$ & $1.40^{*}$ & $4.0^{* *}$ & $0.5^{* *}$ & $0.30^{* *}$ & $15.00^{* *}$ & $2.00^{* *}$ & $0.20^{* *}$ & $5.5^{* *}$ \\
\hline
\end{tabular}

${ }^{*}$ Critical bulk density above which, there is noticeable poor tuber development; ${ }^{* *}$ Critical soil chemical and nutrient values below which, potato growth and yields are negatively affected. 
types applied soil nutrient below the optimum and yet potato is a heavy feed on $\mathrm{N}$ and $\mathrm{K}[12]$. This indicated that linking farmers to urban markets did not lead to sustainable potato production. This was also revealed by the high bulk density under urban and non-urban market linkages that indicated exposure of the compacted sub soil as a result of soil erosion.

\subsection{Potato Yield Responses to Limiting Soil Nutrients}

Other than, potato fields located on hilltops and far from homesteads (Hilltop - $\mathrm{HH}$ ), there were no significant differences in tuber yields on different field typologies $(\mathrm{p}>0.05)$ (Table 5). Soil potassium was the most limiting nutrient in potato fields located on hilltops and far from homesteads. Potassium follows soil nitrogen in quantity taken up by potato crop [12]. Potassium uptake influences tuber yields and size of tubers as well as a number of tuber quality factors including specific gravity, black-spot bruise susceptibility, chip and fry color, and storage quality. Potassium deficiencies reduce photosynthesis, reducing dry matter and starch formation [12]. Although, there were no significant differences in tuber yields on other field typologies other than Hilltop-HH, soil potassium was also the most limiting nutrients in potato fields located on mid-slopes and near homesteads (Midslope $+\mathrm{HH}$ ) and valley bottoms. Potato fields located on hilltops and near homesteads (Hilltops $+\mathrm{HH}$ ), micro-nutrients were the most limiting. Although soil $\mathrm{P}$ and $\mathrm{N}$ are macro-nutrients taken up in substantial amounts by potato, they were not the most limiting on the different field typologies. Similarly, sulfur (S) was not among the most limiting nutrients on the different field typologies.

\subsection{Responses of Potato Yields to Integrated Soil Nutrients}

Other than tuber yields of grade $\mathrm{C}(<45 \mathrm{~mm})$, there were no significant different

Table 5. Responses of potato yields on applied soil nutrients in different field typologies.

\begin{tabular}{cccccc}
\hline \multirow{2}{*}{ Treatment } & Hilltop + HH & Hilltop - HH & Mid slope + HH & Mid slope - HH & Valley \\
\cline { 2 - 6 } & \multicolumn{5}{c}{ (ton/ha) } \\
\hline 1 & 54.6 & 40.8 & 35.9 & 44.0 & 47.1 \\
2 & 50.9 & 82.2 & 41.9 & 54.2 & 58.3 \\
3 & 47.7 & 58.9 & 39.6 & 55.9 & 57.4 \\
4 & 42.3 & 55.7 & 36.2 & 54.1 & 48.8 \\
5 & 48.7 & 41.0 & 33.3 & 51.2 & 46.8 \\
6 & 47.6 & 52.9 & 38.1 & 49.3 & 56.0 \\
7 & 55.4 & 64.5 & 47.2 & 56.6 & 65.8 \\
8 & 40.4 & 64.3 & 44.5 & 55.9 & 57.9 \\
LSD (p $<$ 0.05) & ns & $\mathbf{1 8 . 4 9}$ & ns & ns & ns \\
se & $\mathbf{2 1 . 2 2}$ & $\mathbf{1 5 . 9 0}$ & $\mathbf{1 7 . 3 3}$ & $\mathbf{1 8 . 7 5}$ & $\mathbf{2 0 . 2 8}$ \\
\hline
\end{tabular}

$1=$ No fertilizer application; $2=\mathrm{N}+\mathrm{P}+\mathrm{K}+\mathrm{S}+\mathrm{Mg}+$ micronutrients; $3=\mathrm{P}+\mathrm{K}+\mathrm{S}+\mathrm{Mg}+$ micronutrients; $4=\mathrm{N}+\mathrm{K}+\mathrm{S}+\mathrm{Mg}+$ micronutrients; $5=\mathrm{N}+\mathrm{P}+\mathrm{S}+\mathrm{Mg}+$ micronutrients; $6=\mathrm{N}+\mathrm{P}+\mathrm{K}$ $+\mathrm{Mg}+$ micronutrients; $7=\mathrm{N}+\mathrm{P}+\mathrm{K}+\mathrm{S}+$ micronutrients; $8=\mathrm{N}+\mathrm{P}+\mathrm{K}+\mathrm{S}+\mathrm{Mg}$. 
Table 6. Variation of potato tuber yields with fertilizer application rates.

\begin{tabular}{|c|c|c|c|c|c|c|}
\hline \multirow{2}{*}{ Treatment } & \multicolumn{3}{|c|}{ Grade yield (ton/ha) } & $\begin{array}{c}\text { Total tuber } \\
\text { yields }\end{array}$ & \multirow{2}{*}{$\begin{array}{l}\text { Marketable } \\
\text { yield }\end{array}$} & \multirow[t]{2}{*}{$\begin{array}{l}\text { Number of } \\
\text { tubers/plant }\end{array}$} \\
\hline & A & B & $\mathrm{C}$ & (to & & \\
\hline Control & 0.18 & 11.7 & 21.8 & 33.7 & 11.9 & 4.88 \\
\hline $\mathrm{N}_{100}+\mathrm{P}_{100}+\mathrm{K}_{100}$ & 1.04 & 20.7 & 33.0 & 54.7 & 21.7 & 6.77 \\
\hline $\mathrm{N}_{0}+\mathrm{P}_{100}+\mathrm{K}_{100}$ & 0.73 & 18.0 & 25.8 & 44.6 & 18.8 & 5.00 \\
\hline $\mathrm{N}_{35}+\mathrm{P}_{100}+\mathrm{K}_{100}$ & 1.38 & 30.5 & 38.1 & 70.0 & 31.9 & 8.10 \\
\hline $\mathrm{N}_{66}+\mathrm{P}_{100}+\mathrm{K}_{100}$ & 2.05 & 35.5 & 30.4 & 68.0 & 37.6 & 6.49 \\
\hline $\mathrm{N}_{100}+\mathrm{P}_{0}+\mathrm{K}_{100}$ & 0.97 & 17.3 & 26.5 & 44.8 & 18.3 & 5.37 \\
\hline $\mathrm{N}_{100}+\mathrm{P}_{33}+\mathrm{K}_{100}$ & 2.02 & 24.3 & 31.4 & 57.8 & 26.4 & 6.26 \\
\hline $\mathrm{N}_{100}+\mathrm{P}_{66}+\mathrm{K}_{100}$ & 1.12 & 24.6 & 33.2 & 58.9 & 25.7 & 6.64 \\
\hline $\mathrm{N}_{100}+\mathrm{P}_{100}+\mathrm{K}_{0}$ & 2.52 & 20.4 & 28.6 & 51.5 & 22.9 & 6.27 \\
\hline $\mathrm{N}_{100}+\mathrm{P}_{100}+\mathrm{K}_{33}$ & 1.63 & 20.5 & 31.2 & 53.3 & 22.1 & 6.42 \\
\hline $\mathrm{N}_{100}+\mathrm{P}_{100}+\mathrm{K}_{66}$ & 1.18 & 22.6 & 31.8 & 55.6 & 23.8 & 6.60 \\
\hline LSD (5\%) & ns & ns & 8.61 & ns & ns & ns \\
\hline se & 3.35 & 31.30 & 16.07 & 41.32 & 32.10 & 3.603 \\
\hline
\end{tabular}

NB: Other than the control, all treatments were given equal amounts of S, Mg and micro nutrients.

responses in tuber yields and number of tubers per plant on integrated soil nutrients $(p>0.05)$ (Table 6). During the study, the experiment was affected by bacterial wilt of potato caused by Ralstonia solanacearum that masked the effects of applied mineral nutrients on potato growth and yields. The disease was one the most important challenge in potato production in the highlands of south-western Uganda. It was known for reducing potato yields up to $100 \%$ [13].

\section{Conclusion}

Soil $\mathrm{K}$ was the single significant limiting soil nutrient in potato production, occurring in potato fields located on hilltops and far from homesteads. Therefore, it was imperative for farmers to apply $\mathrm{K}$ containing soil nutrient resources in potato fields to minimize land degradation while improving potato productivity under smallholder farming systems in the highlands of south-western Uganda. However, there was need to integrate disease management to improve potato productivity through integrated soil nutrient management.

\section{Acknowledgments}

The authors would like to acknowledge The Belgium Technical Cooperation (BTC) for funding the study. Sincere thanks go to farmers in the highlands of south-western Uganda for their invaluable time and land accorded to this study.

\section{References}

[1] Koohafkan, P. (2011) The State of the World's Land and Water Resources for Food 
and Agriculture: Managing Systems at Risk. Food and Agriculture Organization of the United Nations, Rome.

[2] Rashid, S., Dorosh, P., Malek, M. and Lemma, S. (2013) Modern Input Promotion in Sub-Saharan Africa: Insights from Asian Green Revolution. Agricultural Economics, 44, 705-721. https://doi.org/10.1111/agec.12083

[3] Dawson, N., Martin, A. and Sikor, T. (2016) Green Revolution in Sub-Saharan Africa: Implications of Imposed Innovation for the Wellbeing of Rural Smallholders. World Development, 78, 204-218.

https://doi.org/10.1016/j.worlddev.2015.10.008

[4] Gildemacher, P.R. (2012) Innovation in Seed Potato Systems in Eastern Africa. Ph.D. Thesis, Wageningen University, Wageningen.

[5] Wang, N., Jassogne, L., van Asten, P.J.A., Mukasa, D., Wanyama, I., Kagezi, G. and Giller, K.E. (2015) Evaluating Coffee Yield Gaps and Important Biotic, Abiotic, and Management Factors Limiting Coffee Production in Uganda. European Journal of Agronomy, 63, 1-11. https://doi.org/10.1016/j.eja.2014.11.003

[6] Adong, A. (2014) Impact of Households' Membership of Farmer Groups on the Adoption of Agricultural Technologies in Uganda: Evidence from the Uganda Census of Agriculture 2008/09. Agrekon, 53, 108-136.

https://doi.org/10.1080/03031853.2014.915485

[7] National Environment Management Authority (2010) Environmental Sensitivity Atlas for the Albertine Graben. Second Edition 2010.

[8] UBOS (2014) National Population and Housing Census 2014. Provisional Results.

[9] Carswell, G. (2003) Continuities in Environmental Narratives: The Case of Kabale, Uganda, 1930-2000. Environment and History, 9, 3-29. https://doi.org/10.3197/096734003129342755

[10] Okalebo, J.R., Gathua, K.W. and Woomer, P.L. (2002) Laboratory Methods of Soil and Plant Analysis: A Working Manual. 2nd Edition, Sacred African Publishers, Nairobi.

[11] Davidson, D.T. (1965) Penetrometer Measurements. In: Black, C.A., Evan, D.D., Ensminger, L.E., White, J.L. and Clark, F.E., Eds., Methods of Soil Analysis. Part 1: Physical and Mineralogical Properties Including Statistics of Measurement and Sampling, American Society of Agronomy, Madison, Inc., WI, 472-484.

[12] Stark, J., Westermann, D. and Hopkins, B. (2004) Nutrient Management Guidelines for Russet Burbank Potatoes. University of Idaho Extension Bulletin No. 840, 1-12.

[13] FAO (2010) Strengthening Potato Value Chains. Technical and Policy Options for Developing Countries. The Food and Agriculture Organization of the United Nations and the Common Fund for Commodities, Rome, 150. 